\title{
Evaluation of An Educational Media on Cube Nets Based on Learning Effectiveness and Gamification Parameters
}

\author{
https://doi.org/10.3991/ijet.v14i14.10505
}

\author{
Iffatu Wardani $\left.{ }^{(}\right)$, Herman Tolle, Ismiarta Aknuranda \\ Brawijaya University, Malang, Indonesia \\ iffatu.wardani@gmail.com
}

\begin{abstract}
At most of elementary school, students learn cube nets from a books and teacher stories. As a three dimentional structure, a cube also chapter should be taught using three dimentional media. It helps students to imagine the concept of the chapter. A cube has eleven nets; therefore, it may be hard to get all of the nets and present them as media in front of students. This paper proposes a media education for cube nets learning. The media is software that developed for desktop utilizing. The software product from this method is tested to elementary school student. A pretest and posttest are applied to know student's skills about cube nets, before and after they used the application. Using Wilcoxon test, the result shows that p-value $(0.017)<\alpha(0.05)$. In other word, the students gain more scores after they use the educational media. The students are also given a questionnaire to evaluate the application. From the questionnaire, conclude that the motivational affordance gains $87.14 \%$ while the physicological outcome gets $91.67 \%$. Whereas the students give $90.57 \%$ for behavioural outcome.
\end{abstract}

Keywords - Learning media, game-based learning, geometry, mathematics

\section{$1 \quad$ Introduction}

Mathematics is one of the less favourite subjects for student in Indonesia [1], [2], [3], [4]. Generally, almost all of materi in mathematics are distated by students. But there are some chapters that difficult to be told, or need some strategy or more effort to teach. One of these chapter is geometry [5]. In the PISA and TIMSS study, geometry is important chapter that being the student's weakness [6]. Whereas, geometry is often used in daily life and used in many other subjects such as physics, computer science and art.

In order to correct the mistake, a work can be tried and to improve student ability in geometry. To be more effective, it's better to improve when students in elementary school [7]. The reason is, in elementary school students learning the most basic concept. When there is unsolving problem while learning basic, it might create bigger difficulties later. So, it would be much better to make elementary school student to clearly understand about geometry. Student in elementary school, learn several chapter of geometry. One of them is cube nets. 
There are many different ways to teach geometry. What is clear is that it cannot be taught using story telling method. The learning process needs more realistic media so the students can imagine the chapter about three dimentional structures [8], [9], [10]. Many teachers try to implement that idea eventough it's not perfect. When students learn about cube nets, they are given one or two nets modelling that can be turn into a cube. In fact, there are eleven different cube nets known. Therefore, students felt unfamiliar with some of the nets.

There are some researches which take cube nets as a topic. Maida [11] make the student learn cube nets using sketchpad. Students should click, drag and down, and print the cube nets. It can be said that the steps to form a net is a bit complicated. Another research is conducted by Sapti [12]. In this research, a cube model is given to the students. They learn how cube nets formed by cutting the edge of the cube. There are many possibility and combination to form a net, and it lay heavy on students. They confuse which edge shuld they choose in order to form cube nets.

While in the topic of evaluation for educational media, there are some researchs with various discussions. Some researchs discuss about effectiveness of learning using educational media with quantitative method and see the difference through pretest and posttest average score, standard deviation and percentage [13], [14]. Other research discusses the learning effectiveness using naration explanation and discuss the difference between learning with and without the media [15].

Research in this paper conducted to help student learning cube nets using educational media that developed for desktop computer. The three dimentional idea is brought in to the software. The media contains learning and exercise for cube nets chapter. To add some fun and enjoyable experiment, a gamification is added to the media.

The learning effectiveness from the media will be examined using statistical analysis, while the gamification is analysed using three parameters. The three parameters are motivational affordance, behavioural outcome and psychological outcome.

\section{Research Method}

This research set a main focus on find out whether the developed educational media can help student understanding cube nets in elementary school.

\subsection{Media overview}

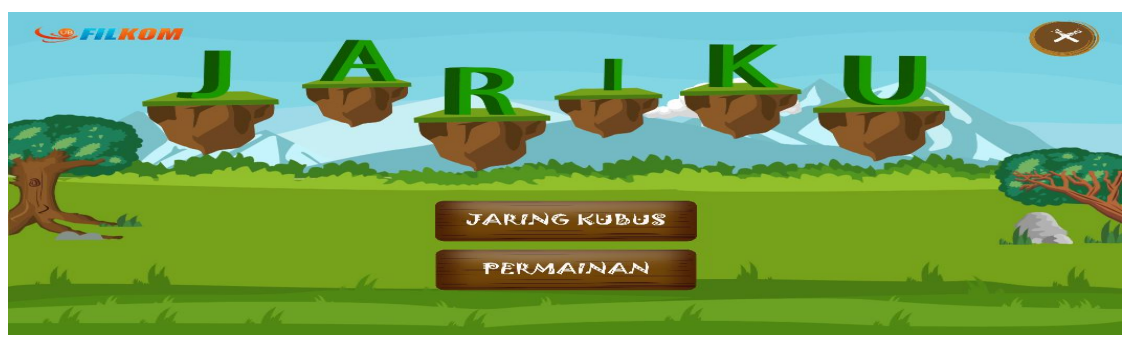

Fig. 1. Educational media for cube nets 
The educational media contains a learning modelling for cube nets. The cube models are made by Blender software. While the entire media, developed using Unity game engine. The media is developed for personal coputer or laptop user. The name of the media is 'Jariku', stands for jaring-jaring kubus which means cube nets. There are two main functions of the media, learning and exercise. The main menu of Jariku is shown in Figure 1.

Learning fuction can be found in Jaring Kubus menu. There are eleven different illustration of cube nets in the menu. The illustration made as if the net forming a real cube because it uses three dimentional structures. With the educational media, student also can-do exercise by using the other menu i.e. Permainan. Student will get a riddle and evaluate their knowledge about cube nets in this menu. With those menues, student can observe, experimenting, associating and communicating while using the media. They are important activities to be done in order to gain more effective result in study [16].

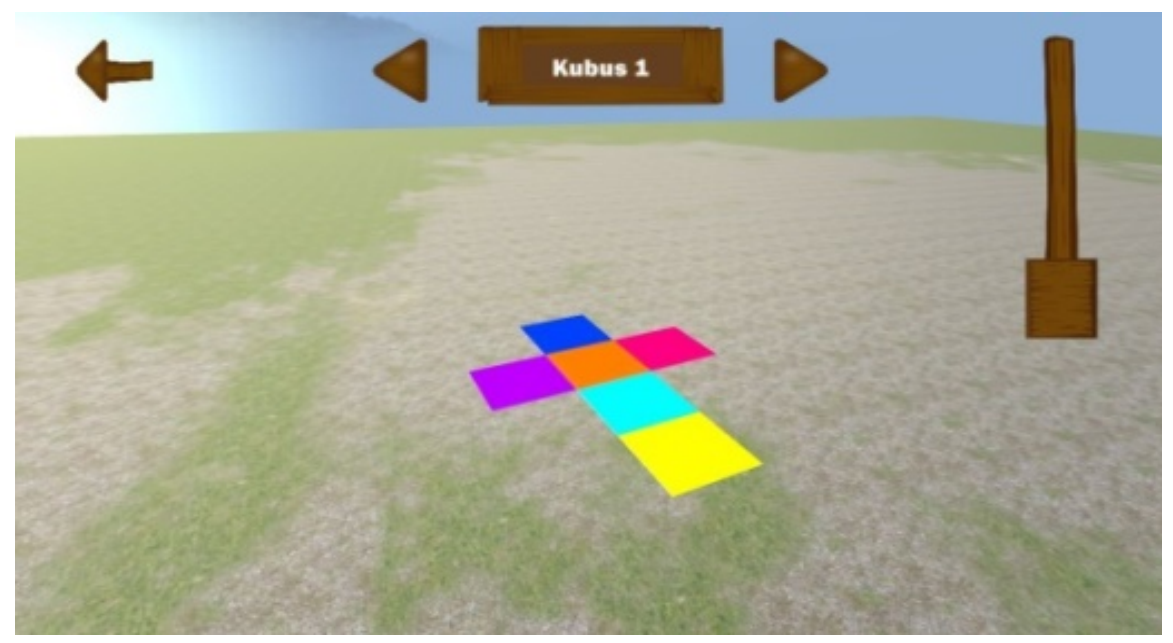

Fig. 2. Learning content for cube nets

\subsection{Learning content}

The educational media developed in this research, ilustrates all of eleven cube nets. Students can actively interact with the illustration. The appearance of the illustration can be changed. It can be formed a net or a cube. When the slider in the right screen is dragged upside, every faces of the nets will be sealed and a cube shape will appear. Whereas the slider dragged downside, the faces of the cube will be open air and the illustration will change into nets form. Figure 3 show the changing process of the illustration. 

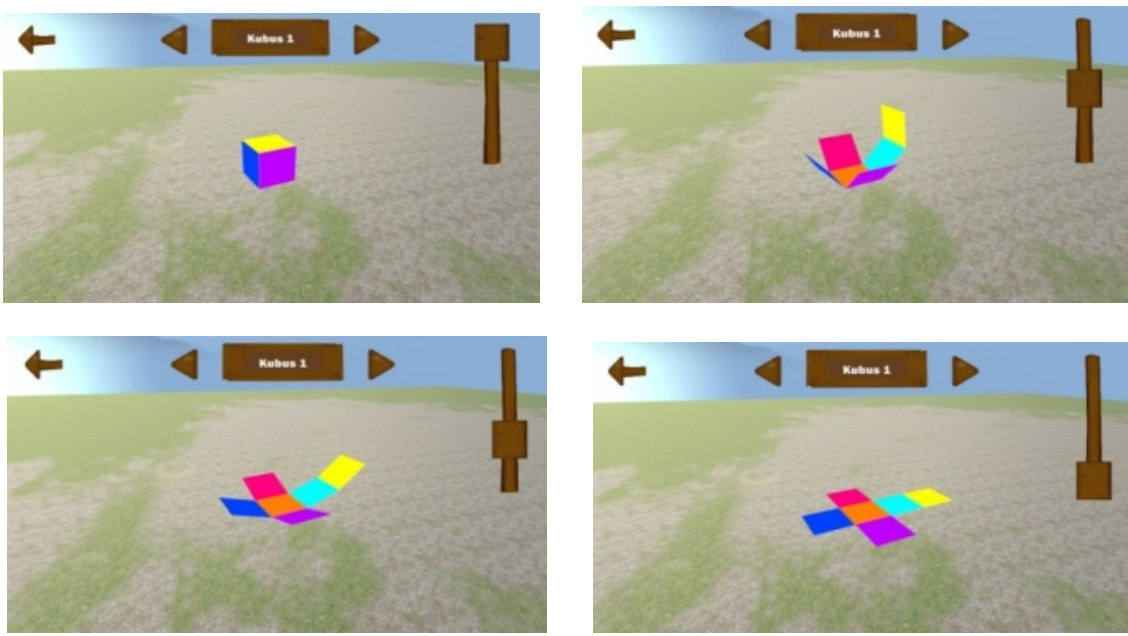

Fig. 3. The shape of illustration can be changed

The illustration also can be rotated so student can recognise a net with its rotated form. A net can be seem different from other, even actually it just same net with different point of view. With the rotated net feature, student expected to know that two nets are not different just because it's rotated. In this educational media, students can rotate the nets by moving the mouse or mousepad to the left or right. The example of rotated nets is shown in Figure 4.
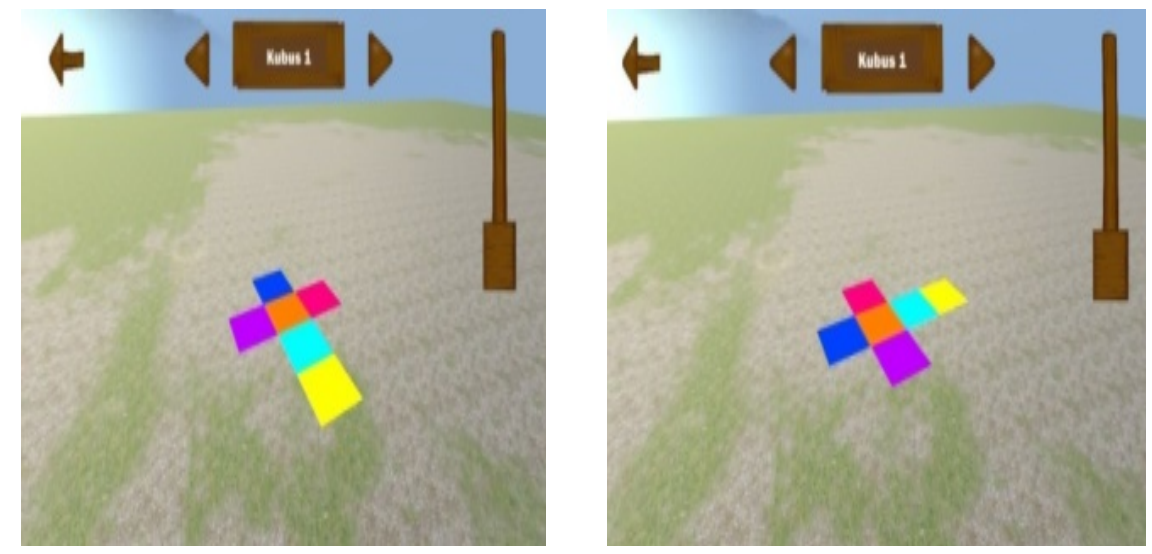

Fig. 4. Nets can be rotated

Figure 4 shows same nets but in different point of view. The net on the right side is rotated about $90^{\circ}$. If the nets rotated in different degree it may looks a bit different too. In this media, students can freely rotate the nets from $0^{\circ}$ to $360^{\circ}$. Students can 
observe every net in every degree movement. The colour of nets' face also different one to another. It might help student to differentiate or mark the faces when it rotate.

Actually, in Jariku educational media, there are eleven illustration of different nets. To move from one net to another, students can use next and previous button on the screen. And all of the nets can be changed to form a cube, and also they can be rotated. Every net labeled from 'Kubus 1' to 'Kubus 11'. The next and previous button laid on the right and left side of the label. The eleven nets are shown in Figure 5.
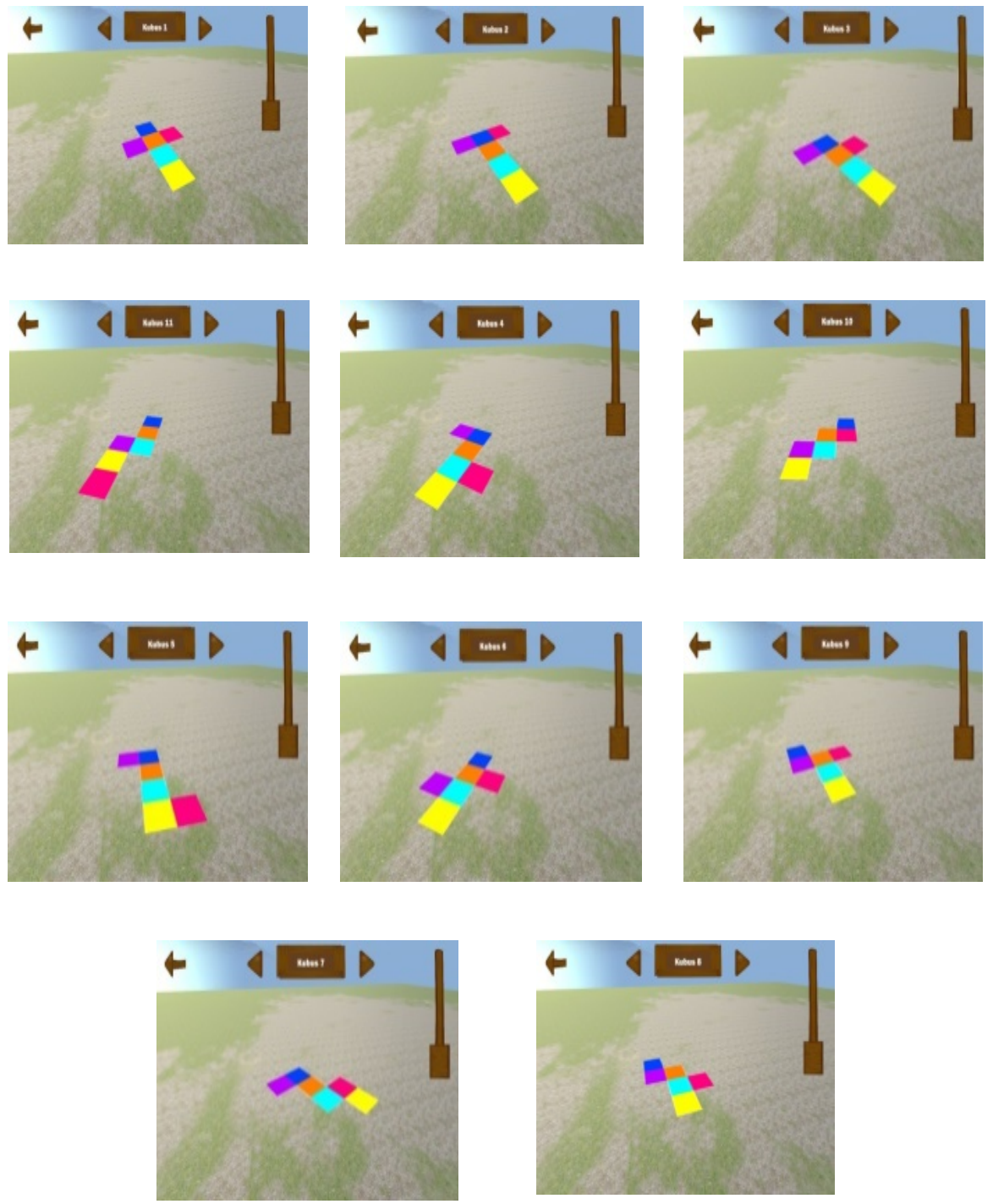

Fig. 5. Eleven different nets 


\subsection{Exercise content}

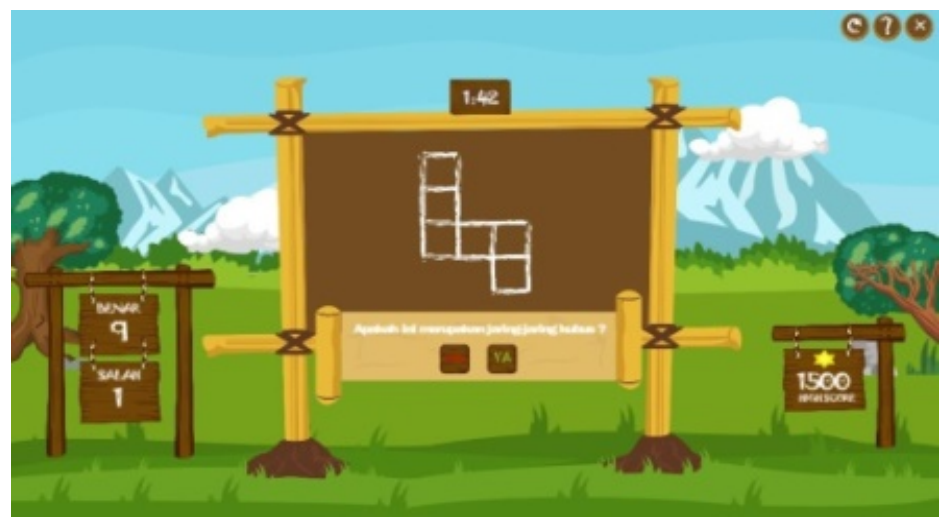

Fig. 6. Riddle of cube nets

On the exercise content, the application adopts a game or put a gamification on it. The reason is to make the application more fun because people of all ages, include elemntary school kids like to play games [17]. In the exercise menu, Jariku provide fifteen riddles to be answerred by the students. A picture of cube nets or something similar to cube nets appears. Student will guess whether it is cube nets or not. Students answer the question trough a button under it. Jariku will notice the student about their answer, is it right answer or wrong answer. The sum of right answer and wrong answer will be shown on the screen. On the screen also appear the highest score gained by user. Figure 6 show the riddle menu.

The fifteen riddles which appear on the screen is random question between cube nets and not cube nets. It's avoiding the student for memorising the question and the answer. After a student finishing one set riddle, the score will appear alongside the highscore gained before. The appearance when the game of the riddle end is shown in Figure 7.

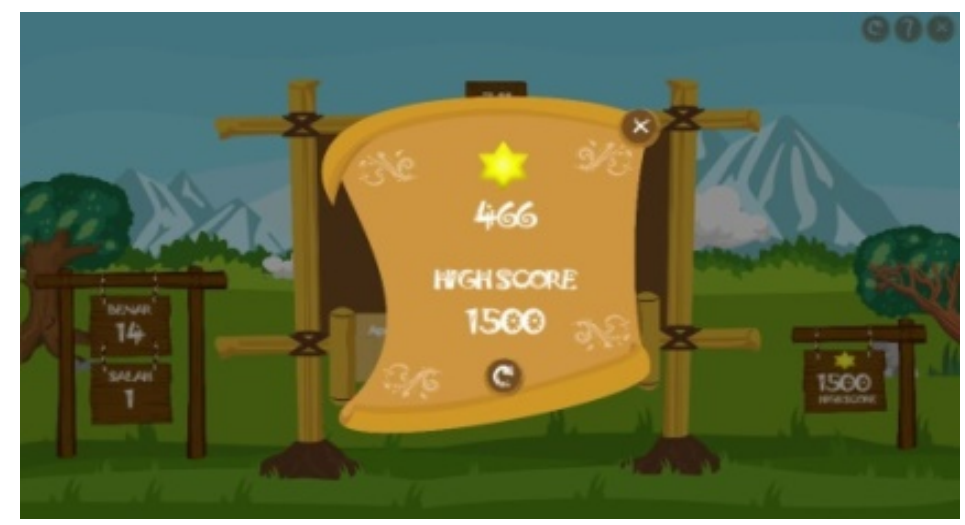

Fig. 7. Pop up score 


\subsection{Participant}

A class contain of 28 students take participate in examining the educational media. The students are from elementary school. They already get cube nets chapter by conventional learning method without media. The examination has a goal to see the difference between study without media and with media. The process of the examination takes two days. At the first day, a pretest is given to the students before they use educational media. Henceforth, students try the media for sixty minutes. At the second day, they study over again using Jariku for same amount of time. The last step is giving posttest to the student at the end of the second day. Alongside with the post test, there is questionnaire to know how much the gamification work in the media.

\subsection{Learning effectiveness measurement}

Learning effectiveness from the media can be measured using pretest and posttest. The two tests contain different questions but same total number and same type of questions. The tests composed to know the student's knowledge about cube nets. An elementary school teacher confirms the question and gives some advices regarding the type of question, the time execution and scoring the result.

\subsection{Gamification measurement}

Gamification is adding some game fature to a non-game object. The adding process has a purpose to give same experience as playing the game [18]. But in educational media, user not only expected to get enjoyment only, but also understand what message the media deliever [19]. Therefore, an educational media should reduce the complexity of game design [20]. With consideration explained before, educational media Jariku, adding some game feature i.e. challanging the student, asking for one clear goal and giving score for the riddle, and provide the highest score for user to compare with their own.

The educational media of this research, is developed with expectation to help the cube nets learning process. In addition, students get the enjoyment while using the media. To measure the gamification, there are three parameters i.e. motivational affordance, psychological outcome and behavioural outcome [18]. In this research, students were given a questionnaire about educational media. The questionnaire contains fifteen statements which five statements for each parameter. For each statement, students can give five different comments. The comment is agree, strongly agree, disagree, strongly disagree and neutral. Later the comment converted to number in order to do further analysis. The convertion of the comment is shown in Table 1.

Table 1. Convertion from comment to number

\begin{tabular}{|c|c|}
\hline Comment & Number Convertion \\
\hline Strongly agree & 5 \\
\hline Agree & 4 \\
\hline Neutral & 3 \\
\hline Disagree & 2 \\
\hline Strongly disagree & 1 \\
\hline
\end{tabular}


In the questionnaire, motivational affordance related to gained ponit, challenge, a clear goal and reward. Include in it, the wishful of the user to explore the media. Psychologycal outcome represents the measurement of user enjoyment. This parameter report whether user gained the similar excitement between playing game and using the media. The last parameter is behavioural outcome. Behavioural outcome indicate that media is easy to learn, the explanation is understandable, the media make the learning process easier and quicker. List of the statement in the questionnaire is shown in Table 2.

Table 2. Statements of questionnaire

\begin{tabular}{|c|c|}
\hline No. & Statements \\
\hline 1. & I want to get a high score when playing the game in application \\
\hline 2. & I thought that I like the educational media \\
\hline 3. & I thought that I quickly recognised cube nets after I use the educational media \\
\hline 4. & I thought that I want to get the highest score \\
\hline 5. & Jariku educational media help me understanding the cube nets \\
\hline 6. & I thought I was challanged to answer all question correctly \\
\hline 7. & I would rather learn nets trough Jariku than learning trough book \\
\hline 8. & I thought that Jariku give clear illustration of the cube nets \\
\hline 9. & I thought I want to know all of the cube nets using Jariku \\
\hline 10. & I thought that learning using Jariku is fun \\
\hline 11. & After learning using Jariku, I thought answering cube nets question is easier \\
\hline 12. & I want to know how to close and open the cube nets trough Jariku \\
\hline 13. & I thought learning cube nets is fun using Jariku \\
\hline 14. & After using Jariku, I thought I gain more control over cube nets \\
\hline 15. & \\
\hline
\end{tabular}

\section{$3 \quad$ Result and Analysis}

\subsection{Learning effectiveness}

As shown in Table 3 and Figure 8, the result of pretest and posttest show the difference between the averages of two samples. Average of pretest score is 81.42, and average of posttest is 88.75 . The two tests have 7.33 difference of average. To know if the two samples significantly different or not, the data will be analysed using statistical method using Wilcoxon. This method is chosen because the data's distribution is not normal and has two dependent samples. In this research, defined $\mathrm{H}_{0}$, which means two samples are not significantly different. And $\mathrm{H}_{1}$ is the first sample (pretest) less than second sample (posttest) and $\alpha=0.05$. 


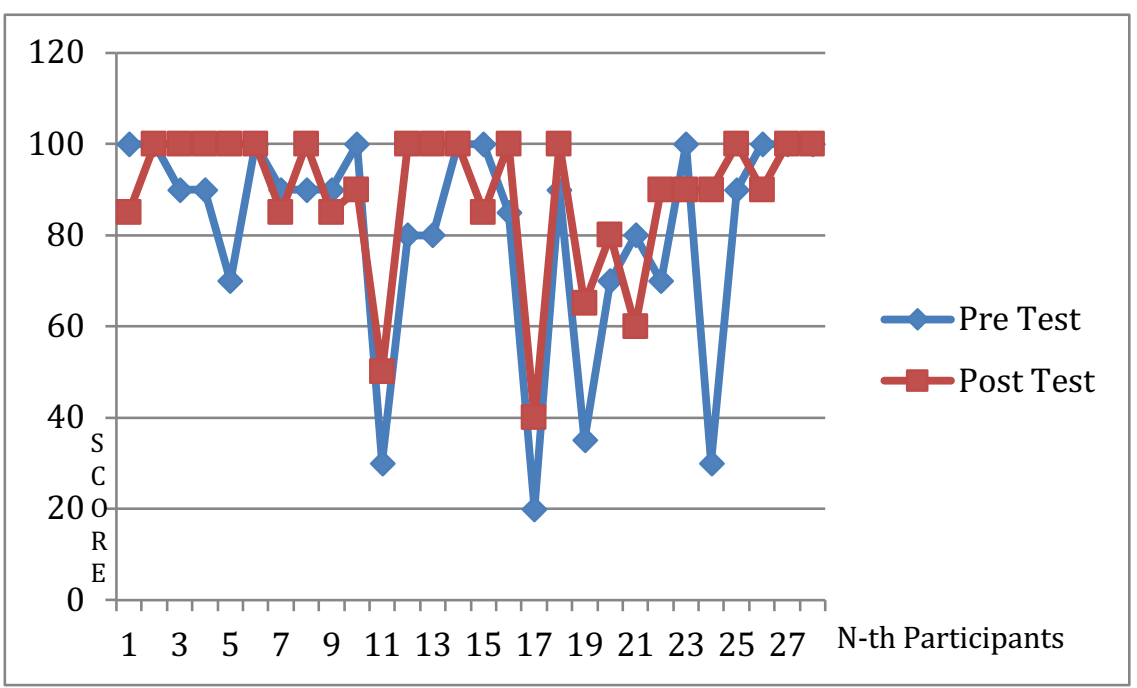

Fig. 8. Graphic score pretest and post test

Table 3. Pre test and post test score

\begin{tabular}{|c|c|c|c|c|c|c|c|}
\hline \multicolumn{9}{|c|}{ Pre-Test } & \multicolumn{4}{c|}{ Post Test } \\
\hline Student & Score & Student & Score & Student & Score & Student & Score \\
\hline 1 & 100 & 15 & 100 & 1 & 85 & 15 & 85 \\
\hline 2 & 100 & 16 & 85 & 2 & 100 & 16 & 100 \\
\hline 3 & 90 & 17 & 20 & 3 & 100 & 17 & 40 \\
\hline 4 & 90 & 18 & 90 & 4 & 100 & 18 & 100 \\
\hline 5 & 70 & 19 & 35 & 5 & 100 & 19 & 65 \\
\hline 6 & 100 & 20 & 70 & 6 & 100 & 20 & 80 \\
\hline 7 & 90 & 21 & 80 & 7 & 85 & 21 & 60 \\
\hline 8 & 90 & 22 & 70 & 8 & 100 & 22 & 90 \\
\hline 9 & 90 & 23 & 100 & 9 & 85 & 23 & 90 \\
\hline 10 & 100 & 24 & 30 & 10 & 90 & 24 & 90 \\
\hline 11 & 30 & 25 & 90 & 11 & 50 & 25 & 100 \\
\hline 12 & 80 & 26 & 100 & 12 & 100 & 26 & 90 \\
\hline 13 & 80 & 27 & 100 & 13 & 100 & 27 & 100 \\
\hline 14 & 100 & 28 & 100 & 14 & 100 & 28 & 100 \\
\hline \multicolumn{7}{|l}{ Average: 81.42} & \multicolumn{5}{l}{ Average: 88.75} \\
\hline
\end{tabular}




\title{
Wilcoxon Signed Rank Test: Difference
}

\author{
Method \\ $\eta$ : median of Difference
}

Descriptive Statistics

\begin{tabular}{lrr} 
Sample & $N$ & Median \\
\hline Difference & 28 & -5
\end{tabular}

Test

Null hypothesis $\quad H_{0}: \eta=0$

Alternative hypothesis $H_{1}: \eta<0$

\begin{tabular}{lrrr} 
& $\begin{array}{r}N \text { for } \\
\text { Sample }\end{array}$ & Wilcoxon & \\
\hline Tifference & 23 & 67.50 & 0.017
\end{tabular}

Fig. 9. Wilcoxon test

From the calculation as shown in Figure 9, obtained p-value $=0.017$. Compared with $\alpha, \mathrm{p}$-value is less than 0.05 so $\mathrm{H}_{0}$ is declined and $\mathrm{H}_{1}$ is accepted. In other word, the post test score is better than pretest score. After the students using the application, they gained more score for cube nets subject.

\subsection{Gamification}

Table 4 show the student's comment after converted to number. But before analyse the result further, the validity and reliability of the questionnaire's statement should be tested. Validity is checked to determine whether the statement can be used to measure the parameter. If there are many invalid statements, students must fill the questionnaire again. But if the invalid statements just a few, it can be ignored. After validity test a reliability also done to the questionnaire. Reliability test determine the consistency of the questionnaire. Questionnaire reliable means the result of the questionnaire will not be much different if the study is conducted on other sample, other time and another place. 
Table 4. Questionnaire result

\begin{tabular}{|c|c|c|c|c|c|c|c|c|c|c|c|c|c|c|c|c|}
\hline \multirow{2}{*}{ Student } & \multicolumn{16}{|c|}{ Statement } \\
\hline & 1 & 2 & 3 & 4 & 5 & 6 & 7 & 8 & 9 & 10 & 11 & 12 & 13 & 14 & 15 & Sum \\
\hline 1 & 5 & 4 & 4 & 4 & 5 & 5 & 4 & 5 & 5 & 4 & 5 & 4 & 3 & 5 & 3 & 65 \\
\hline 2 & 5 & 5 & 5 & 5 & 5 & 5 & 5 & 3 & 4 & 5 & 5 & 5 & 5 & 5 & 4 & 71 \\
\hline 3 & 4 & 4 & 4 & 5 & 4 & 4 & 5 & 2 & 4 & 4 & 4 & 4 & 4 & 4 & 3 & 59 \\
\hline 4 & 5 & 5 & 5 & 5 & 5 & 5 & 5 & 1 & 5 & 5 & 5 & 5 & 4 & 4 & 5 & 69 \\
\hline 5 & 3 & 4 & 5 & 3 & 4 & 5 & 4 & 5 & 4 & 5 & 5 & 5 & 5 & 4 & 4 & 65 \\
\hline 6 & 5 & 5 & 5 & 5 & 5 & 5 & 5 & 5 & 5 & 5 & 5 & 5 & 5 & 5 & 5 & 75 \\
\hline 7 & 3 & 4 & 4 & 2 & 4 & 5 & 5 & 1 & 4 & 5 & 5 & 5 & 4 & 4 & 5 & 60 \\
\hline 8 & 5 & 5 & 5 & 5 & 1 & 5 & 5 & 5 & 2 & 5 & 5 & 5 & 5 & 5 & 5 & 68 \\
\hline 9 & 5 & 5 & 5 & 5 & 5 & 5 & 5 & 4 & 5 & 5 & 4 & 5 & 5 & 4 & 5 & 72 \\
\hline 10 & 4 & 5 & 5 & 3 & 4 & 5 & 4 & 2 & 4 & 4 & 4 & 4 & 5 & 5 & 5 & 63 \\
\hline 11 & 5 & 4 & 5 & 5 & 5 & 4 & 3 & 5 & 4 & 5 & 4 & 3 & 2 & 2 & 3 & 59 \\
\hline 12 & 4 & 4 & 4 & 4 & 5 & 4 & 4 & 3 & 4 & 5 & 5 & 4 & 5 & 4 & 4 & 63 \\
\hline 13 & 5 & 5 & 5 & 4 & 5 & 5 & 5 & 4 & 5 & 5 & 5 & 5 & 5 & 5 & 5 & 73 \\
\hline 14 & 5 & 4 & 5 & 4 & 5 & 5 & 5 & 3 & 5 & 5 & 5 & 5 & 5 & 5 & 5 & 71 \\
\hline 15 & 4 & 4 & 5 & 4 & 4 & 4 & 4 & 4 & 5 & 4 & 5 & 4 & 5 & 4 & 5 & 65 \\
\hline 16 & 5 & 5 & 4 & 5 & 4 & 5 & 4 & 4 & 5 & 4 & 5 & 4 & 4 & 5 & 4 & 67 \\
\hline 17 & 5 & 5 & 5 & 4 & 5 & 5 & 4 & 4 & 5 & 5 & 5 & 4 & 5 & 4 & 5 & 70 \\
\hline 18 & 5 & 5 & 5 & 5 & 5 & 5 & 5 & 5 & 4 & 5 & 5 & 5 & 4 & 5 & 5 & 73 \\
\hline 19 & 4 & 4 & 3 & 4 & 4 & 4 & 3 & 3 & 4 & 4 & 4 & 3 & 4 & 4 & 3 & 55 \\
\hline 20 & 5 & 5 & 5 & 5 & 4 & 4 & 4 & 3 & 4 & 5 & 5 & 5 & 4 & 4 & 3 & 65 \\
\hline 21 & 3 & 5 & 5 & 4 & 5 & 5 & 4 & 3 & 4 & 5 & 5 & 4 & 5 & 4 & 5 & 66 \\
\hline 22 & 3 & 5 & 4 & 4 & 5 & 4 & 4 & 3 & 4 & 5 & 4 & 5 & 4 & 4 & 5 & 63 \\
\hline 23 & 5 & 5 & 5 & 5 & 5 & 5 & 2 & 1 & 5 & 5 & 5 & 5 & 4 & 5 & 5 & 67 \\
\hline 24 & 5 & 5 & 5 & 5 & 4 & 4 & 3 & 5 & 3 & 1 & 5 & 3 & 1 & 2 & 4 & 55 \\
\hline 25 & 5 & 5 & 5 & 5 & 5 & 5 & 3 & 2 & 5 & 5 & 5 & 5 & 5 & 5 & 5 & 70 \\
\hline 26 & 5 & 5 & 5 & 5 & 5 & 5 & 4 & 2 & 5 & 5 & 5 & 5 & 5 & 5 & 5 & 71 \\
\hline 27 & 4 & 4 & 4 & 4 & 5 & 5 & 2 & 2 & 4 & 4 & 4 & 5 & 5 & 5 & 4 & 61 \\
\hline 28 & 4 & 5 & 5 & 4 & 5 & 5 & 4 & 4 & 5 & 4 & 5 & 5 & 4 & 5 & 4 & 68 \\
\hline
\end{tabular}

Software SPSS is used to test the validity and reliability. Table 5 show the result of validity test. $\mathrm{R}$ Table selected based on $\mathrm{N}-2=26$ ( $\mathrm{N}$ the number of respondent) on significancy level 0.05 i.e. 0.374 . the statement is valid when the value of Pearson correlation $>\mathrm{R}$ Table and significancy value $<0.05$.

Validity test result shows that there are three statement that not valid. There are statements number 4, 5 and 8 . The three statement have Pearson correlation $<\mathrm{R}$ table $(0.374)$ and significancy value $<0.05$. This problem can be caused by students do not understand the chosen words in the statement. In other case, this problem happen when the students' comments too diverse.

After validity test, the valid statements tested the reliability. The questionnaire has Cronbach's Alpha value $=0.817>0.6$ so it's reliable as shown in Figure 10. The conclusion from the test is all of the valid statement is reliable. Analysis can be continued to the next step. 
Table 5. Validity of each statement

\begin{tabular}{|c|c|c|c|c|}
\hline Statement & Pearson Correlation & $\begin{array}{c}\text { R Table } \\
(\mathbf{N - 2 = 2 6 )}\end{array}$ & Significancy & Validity \\
\hline 1 & 0.451 & 0.374 & 0.016 & Valid \\
\hline 2 & 0.530 & 0.374 & 0.004 & Valid \\
\hline 3 & 0.585 & 0.374 & 0.001 & Valid \\
\hline 4 & 0.290 & 0.374 & 0.135 & Unvalid \\
\hline 5 & 0.268 & 0.374 & 0.168 & Valid \\
\hline 6 & 0.666 & 0.374 & 0.000 & Valid \\
\hline 7 & 0.492 & 0.374 & 0.008 & Unvalid \\
\hline 8 & 0.128 & 0.374 & 0.516 & Valid \\
\hline 9 & 0.489 & 0.374 & 0.008 & Valid \\
\hline 10 & 0.575 & 0.374 & 0.001 & Valid \\
\hline 11 & 0.475 & 0.374 & 0.011 & Valid \\
\hline 12 & 0.683 & 0.374 & 0.000 & Valid \\
\hline 13 & 0.575 & 0.374 & 0.001 & Valid \\
\hline 14 & 0.625 & 0.374 & 0.000 & 0.001 \\
\hline 15 & 0.587 & 0.374 & & \\
\hline
\end{tabular}

Reliability Statistics

\begin{tabular}{|r|r|}
\hline $\begin{array}{c}\text { Cronbach's } \\
\text { Alpha }\end{array}$ & N of Items \\
\hline .817 & 12 \\
\hline
\end{tabular}

Fig. 10. Reliability test

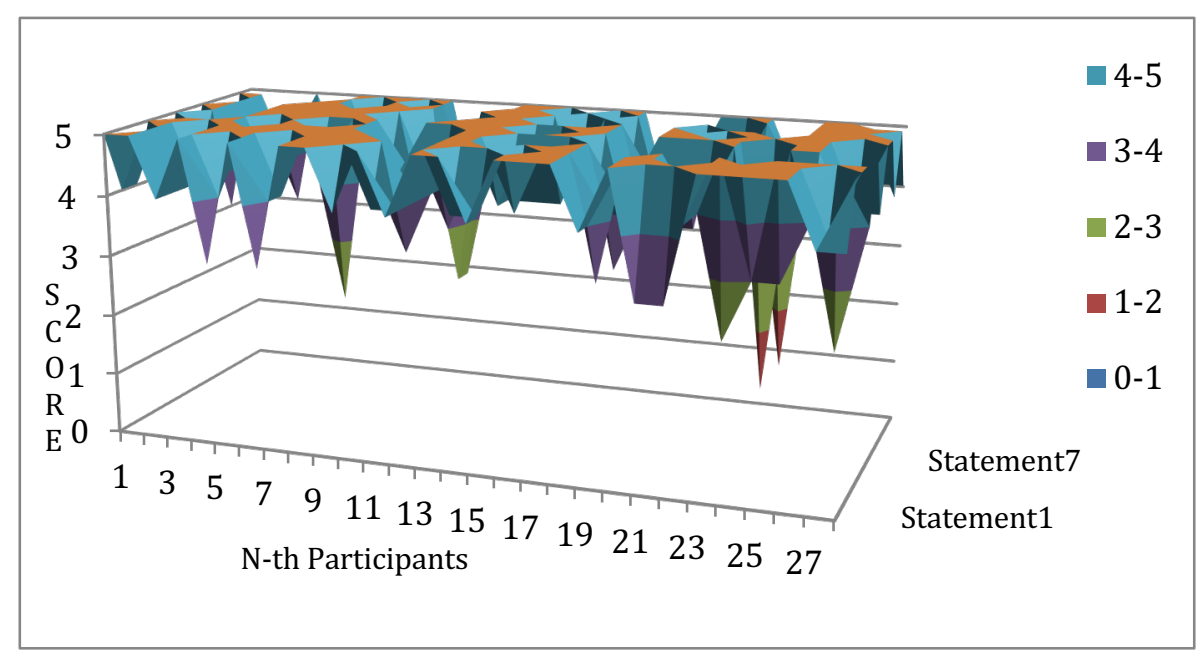

Fig. 11. Visualization for questionnaire result

Figure 11 show the visualisation of the questionnaire. Almost all of students give the high score for the media. It shows the positive response from the users. Table 6 
show the average percentage of valid and reliable statement. These data categorised again based on parameter of gamification. And the next step is analysing the questionnaire. Table 7 show the average percentage of each parameter.

Table 6. Average percentage for valid and reliable statement

\begin{tabular}{|c|c|c|}
\hline No. & Statement & Average (\%) \\
\hline 1. & 1 & 89.29 \\
\hline 2. & 2 & 92.86 \\
\hline 3. & 3 & 93.57 \\
\hline 4. & 6 & 94.29 \\
\hline 5. & 7 & 81.43 \\
\hline 6. & 9 & 87.14 \\
\hline 7. & 10 & 91.42 \\
\hline 8. & 11 & 95.00 \\
\hline 9. & 12 & 90.00 \\
\hline 10. & 13 & 86.43 \\
\hline 11. & 14 & 87.14 \\
\hline 12. & 15 & 87.86 \\
\hline
\end{tabular}

Table 7. Average score for each parameter

\begin{tabular}{|c|c|c|c|}
\hline No. & Parameters & Statement Number & Average (\%) \\
\hline 1. & Motivational Affordance & $1,7,10,13$ & 87.14 \\
\hline 2. & Psychological Outcome & $2,11,14$ & 91.67 \\
\hline 3. & Behavioural Outcome & $3,6,9,12,15$ & 90.57 \\
\hline
\end{tabular}

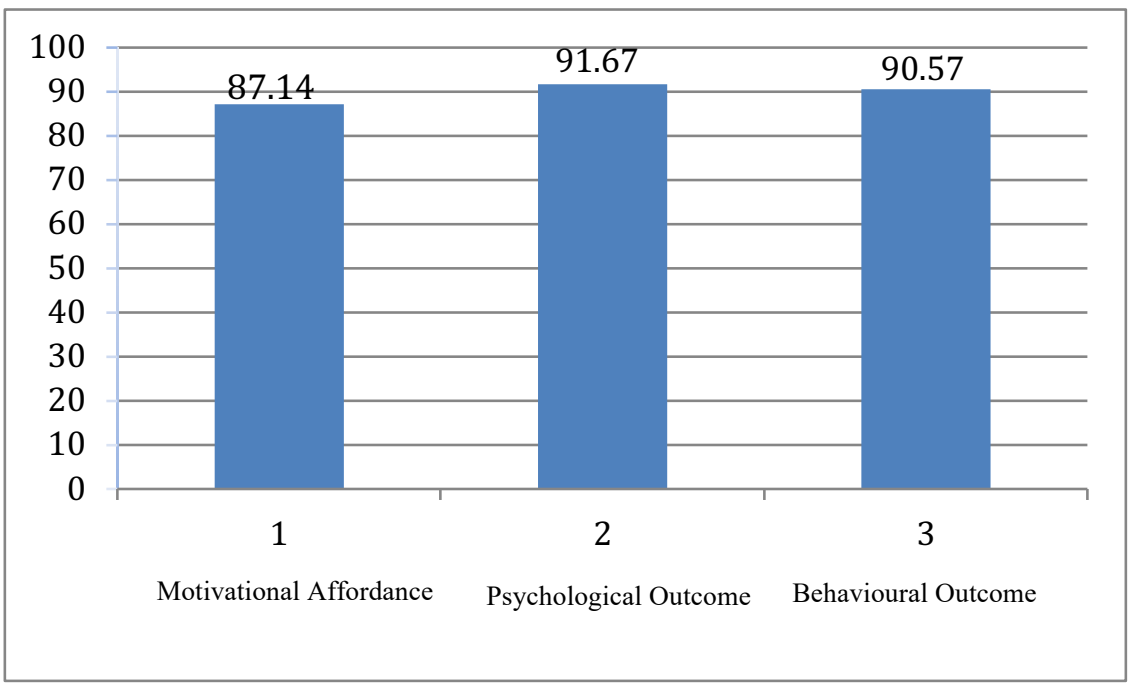

Fig. 12. Gamification evaluation

The chart in Figure 12 shows that Psychological outcome has the highest score among the three parameters. It means, students really enjoy using the educational 
media. In the second place, behavioural outcome also gain high score which means the media helps students to understand cube nets. Even motivational affordance get the lowest score among the three parameters, it cannot be considered low score. It also gains a high score which means students want to explore and more interact with media.

\section{Conclusion}

Jariku educational media can be used for learning cube nets in elementary school. The media success in delievering all of the gamification parameters. It can challenge students, give the enjoyment and help students understanding the cube nets. This statement can be proven by look at the result of learning effectiveness. Students gain more score after study using Jariku.

For the future research, an educational media can be developed for mobile application. It may give higher effect and more engagement for student. The research also can change the riddle on the media, and replaced it with something better that still give enjoyment and help students understanding the cube nets.

\section{Acknowledgement}

Thanks to Faculty of Computer Science, Brawijaya University for supporting this research. Acknowledgement also for elementary school students, teacher and anyone who voluntary help evaluate this educational media.

\section{References}

[1] OECD (2012). PISA 2012 Result in Focus https://www.oecd.org/pisa/ keyfindings/pisa-2012-results-overview.pdf acessed December 1st 2017

[2] OECD (2015). PISA 2015 Result in Focus https://www.oecd.org/pisa/pisa-2015-results-infocus.pdf accessed December, 10th $2017 \mathrm{https}$ ://doi.org/10.1787/3512d7ae-en

[3] IEA (2011). TIMSS 2011 International Result in Mathematics https://timssandpirls.bc.edu/timss2011/downloads/T11_IR_Mathematics_FullBook.pdf acessed December 1st 2017

[4] IEA (2015). TIMSS 2015 International Result in Mathematics http://timss2015.org/wpcontent/uploads/filebase/full\%20pdfs/T15-International-Results-in-Mathematics-Grade4.pdf accessed December 10th 2017

[5] Lehrer, R., \& Chazan, D. (2012). Designing Learning Environments for Developing Understanding of Geometry and Space

[6] S. Srinivas, S. Khanna, J. Rahaman, and V. Kumar, "Designing a Game-Based Learning Environment to Foster Geometric Thinking," Proc. - IEEE 8th Int. Conf. Technol. Educ. T4E 2016, pp. 72-79, 2017. https://doi.org/10.1109/t4e.2016.023

[7] Chen, M. (2013). Designing a RPG Game for Learning of Mathematic Concepts, 217-220. https://doi.org/10.1109/iiai-aai.2013.51 
[8] Chang, T., Hsiao, I. Y. T., Yang, S. J. H., \& Participants, A. (2016). Creating a 3D gamebased learning system in a virtual world for low-achieving students in mathematics, 518519. https://doi.org/10.1109/icalt.2016.37

[9] Christou, Jones, Pantazzi, P., Pittalis, \& Mousoulides. (2007). 3D SOFTWARE APPLICATIONS, 22-26

[10] I. Rizki, D. Renavitasari, A. A. Supianto, and H. Tolle, "Log Data Analysis of Player Behavior in Tangram Puzzle Learning Game," iJIM vol. 12, no. 8, pp. 123-129, 2018. https://doi.org/10.3991/ijim.v12i8.9280

[11] Maida, P. (2005). IUMPST: The Journal, Vol 3 (Technology), August 2005., 3(August).

[12] Sapti, M. (2014). E - 45 Teacher' s Informal Learning Trajectory a nd Student' s Actual Learning Trajectory on Learning Cube and Cuboid Nets.

[13] I. F. Al-mashaqbeh, "IPad in Elementary School Math Learning Setting," pp. 48-52, 2016. http://dx.doi.org/10.3991/ijet.v11i02.5053

[14] M. Al Masarweh, "Evaluating M-Learning System Adoption by Faculty Members in Saudi Arabia Using Concern Based Adoption Model (CBAM) Stages of Concern," vol. 14, no. 5, pp. 153-164, 2019. https://doi.org/10.3991/ijet.v14i05.8296

[15] A. S. Drigas and M. A. Pappas, "A R EVIEW OF M OBILE L EARNING A PPLICATIONS FOR MATHEMATICS. A Review of Mobile Learning Applications for Mathematics.," pp. 18-23, 2004. http://dx.doi.org/10.3991/ijim.v9i3.4420

[16] Musfiqon \& Nurdyansyah. (2015). Pendekatan Pembelajaran Saintifik (Cetakan Pertama). Sidoarjo: Nizamia Learning Center

[17] A. Fairuzabadi, A. A. Supianto, and H. Tolle, “Analysis of Players' Speed Thinking in Color Mix Game Application,” iJIM vol. 12, no. 8, pp. 113-122, 2018. https://doi.org/ 10.3991/ijim.v12i8.9279

[18] Hamari, J., Koivisto, J., \& Sarsa, H. (2014). Does Gamification Work? - A Literature Review of Empirical Studies on Gamification, 3025-3034. https://doi.org/10.1109/hicss. 2014.377

[19] Kebritchi, M., Hirumi, A., \& Bai, H. (2010). Computers \& Education The effects of modern mathematics computer games on mathematics achievement and class motivation. Computers \& Education, 55(2), 427-443. https://doi.org/10.1016/j.compedu.2010.02.007

[20] Ibrahim, Roslina \& Jaafar, Azizah. (2009). Educational Games (EG) Design Framework: Combination of Game Design, Pedagogy and Content Modelling. International Conference of Electrical Engineering and Informatics, August 5-7 2009, Selangor, Malaysia. pp 293298. https://doi.org/10.1109/iceei.2009.5254771

\section{$7 \quad$ Authors}

Iffatu Wardani. is a postgraduate student of Computer Science Faculty, Brawijaya University Malang, Indonesia. She joined the area of interest Multimedia, Game, and Mobile Technologies research group.

Herman Tolle. is a computer scientist, engineering educator, and lecturer at Brawijaya University Malang, Indonesia.

Ismiarta Aknuranda. is a computer scientist, engineering educator, and lecturer at Brawijaya University Malang, Indonesia.

Article submitted 2019-03-20. Resubmitted 2019-04-27. Final acceptance 2019-04-27. Final version published as submitted by the authors. 